European Journal of Logistics, Purchasing and Supply Chain Management

Vol.8 No.3, pp.1-16, August 2020

Published by ECRTD UK

ISSN 2054-0930 (Print), ISSN 2054-0949 (Online)

\title{
SCENARIO ANALYSIS OF AGGREGATE MODEL OF ECOWAS FREIGHT TRANSPORT VOLUMES: AN IMPERATIVE FOR ADOPTION OF SHORT SEA SHIPPING
}

\author{
aElem, T. R., bOgwude, I. C., 'Ibe, C. C., 'Nnadi, K. U. and *bEjem, E. A. \\ ${ }^{a}$ Nigeria Maritime Administration and Safety Agency (NIMASA), Apapa \\ Lagos \\ ${ }^{b}$ Department of Transport Management Technology, Federal University of Technology, Owerri, \\ Imo State, Nigeria \\ 'Department of Maritime Management Technology, Federal University of Technology, Owerri, \\ Imo State, Nigeria \\ P.M.B. 1526, Owerri, Imo State, Nigeria. \\ *Corresponding author: ejemflagospel@yahoo.com
}

\begin{abstract}
This paper shows the effect of changes in GDP, population, foreign trade and seaport access corridors of ECOWAS member countries, especially the littoral States, on the growth of freight volumes of their respective economies. The aim of the paper is to recommend a short sea shipping model for the ECOWAS sub-region, to reduce the cost per transported unit within the sub-region and predict the growth of short sea shipping freight in ECOWAS economies. The research is based on cross-sectional data from ECOWAS countries spanning from 2000 to 2013 and sourced from the ECOWAS Commission and National Bureaus of Statistics of some member countries. The research also showed that the development of short sea shipping model in the subregion would depend considerably on growth in GDP, improvement in the productivity of the population and increase in seaport corridors of the ECOWAS sub-region. This model provides a useful framework for forecasting short-sea shipping freight for the ECOWAS sub-region. Despite the ECOWAS efforts at promoting policies to encourage intra-regional cooperation based on its advantages in terms of energy efficiency, improved intermodality and environmental safety, short sea shipping remains undeveloped compared to road transport mode. The paper concludes that funding opportunities in the sub-region have not offered the right incentives and support to promote short sea shipping. Some critical factors such as the crucial role of port infrastructure and its characteristics have not been taken into full consideration by transport policymakers in the sub-region. This paper suggests the need for ECOWAS member states to prioritise investment in the development of short sea shipping capacity, including the supportive port infrastructure as well as improvement of the entire transport system efficiency.
\end{abstract}

KEYWORDS: Short-sea, shipping, freight, transport, ECOWAS 


\section{INTRODUCTION}

Transportation infrastructure in the ECOWAS sub-region is perceived to be inadequate with unplanned modal coordination. Apart from the road sector, which is relatively more developed, although poorly maintained and with low accessibility to other modes, the other modes of transport need to be investigated especially short sea shipping infrastructure. To be sure, this mode is crucial for intra ECOWAS movement for passenger and freight because of its relative efficiency and economics of scale in moving large amounts of freight over a long distance.

ECOWAS region has an excellent natural network of inland waterways that empty into the Atlantic Ocean, thereby strategically connecting the coastal regions with the main productive hinterlands and markets. Hence it is well endowed with significant potentials for thriving short sea shipping that could boost trade and commerce within and among the countries of the sub-region. Nevertheless, despite the considerable waterways advantage and potentials for short sea shipping as a catalyst to the development and growth of intra ECOWAS trade, short sea shipping service has remained underdeveloped in the sub-region as a result of non-availability of the necessary capacities (soft and hard infrastructure). Consequently, the critical role short sea shipping would have played remains a yawning gap that needs to be immediately studied to ascertain its potentials and possible future to support and promote the development of intra ECOWAS trade. Trade between countries of the ECOWAS sub-region has remained low. This is characteristic of the entire Africa region where intra-regional trade lags behind the world average. There is a growing concern about this trend, especially given the economic and social cost to the sub-region. The concern has become the fresh impetus for considering a strategy to reverse the trade imbalance and has consequently inspired current African leaders to close rank in this direction.

Weak and inefficient transportation infrastructure has been identified as one of the factors that explain the low level of intra-ECOWAS trade. Consequently, efforts have been intensified at the national and sub-regional levels to improve the transportation link between the ECOWAS countries. However, there is a gap on scientific framework for investigating and evaluating the potential of short sea shipping freight in the ECOWAS sub-region as in most other regional economic blocs. This paper is a conscious attempt to provide a robust and reliable empirical formula for structural estimation of modal freight volumes in four (4) different relevant scenarios. In corollary and perhaps more importantly, is to provide, based on unique sub-regional circumstances, a quantitative tool for predicting short sae shipping freight growth in the ECOWAS sub-region. Specifically, the research is primed to provide a structural equation models for estimating modal freight volumes at aggregated and disaggregated levels in both littoral and landlocked ECOWAS member states, as well as a freight growth forecast model for short sea shipping in the sub-region. With this, it is believed that the models would provide empirical rationale for public policy shift towards targeted and coordinated investment in the development of short sea shipping infrastructure either through the upgrading and expansion of existing port facilities or outright greenfield investment. This is because the models would help in determining the quantitative threshold for modal switch in freight transport in the sub-region. 
Flowing from the above, a necessary and vital knowledge gap would have been closed in analysis of freight transport in a key sub-Sahara African region. This paper therefore, provides a general methodology for structural evaluation of freight transport and a maritime freight-specific forecast model for West Africa. Such empirical mechanism would support public sector decision in formulation of short sea shipping oriented regional transport development strategy and policy, as well as private investors' business decision. This paper, therefore provides a scientific approach for evidence based justifications for the development of short sea shipping capacity through a subregional framework within the context of the intra ECOWAS trade development strategy.

\section{LITERATURE REVIEW}

Trade facilitation helps to reduce cost of trade, which in their broadest definition include all costs, excluding the cost of production, incurred in getting useful from a producer to a final consumer (Anderson and Wincoop, 2004). Among other constituents, they include the costs of transportation, tariffs, nontariff measures and inefficient trade procedures. The effects of trade facilitation on a particular market may spill over to other markets, the analysis is extended to a general equilibrium setting using standard models of international trade, from the classical models to the most recent models of global value chains. The early or classical trade models explain why trade emerges between different countries (inter-industry trade) based on differences in productivity (World Trade Report, 2015). While these early trade models do not bring trade costs explicitly into the analysis, later trade models do. The new trade theory (Krugman, 1979; 1980) explains why trade between similar countries (intra-industry trade) takes place because of the demand for variety and increasing returns to scale in production. Finally, a branch of more recent models incorporates differences in the productivity of firms which result in only some of them being able to overcome the fixed trade cost of entering export markets (Melitz, 2003). A second branch focuses on fragmented production and value chains and tells us that trade costs are particularly pernicious because they are cumulated and magnified along the supply chain (Yi, 2010).

The countries may trade the goods they produce with each other by incurring an iceberg transportation cost specific to that good: FK for $\mathrm{k} \in\{\mathrm{m}, \mathrm{x}, \mathrm{c}\}$. The countries each have a government that can impose an ad valorem (net of transport fees) tariff $\tau_{\mathrm{I} k}$ on traded goods $\mathrm{k} \in$ $\{\mathrm{m}, \mathrm{x}, \mathrm{c}\}$. The government gives the domestic representative household transfers $\mathrm{T}_{\mathrm{i}}$ and maintains budget balance. In classical models, gains from trade result because countries are assumed to possess either different relative productivities or endowments of factors of production such as labour, capital and land. In these models, countries specialise in goods in which they have a comparative technological advantage relative to other countries or in goods that use their abundant factors of production more intensively. They then import other goods from their trade partners. These models provide a rationale for inter-industry trade (e.g. a country exporting automobiles and importing wheat) but not intra-industry trade (e.g. a country exporting sports cars and importing sports utility vehicles). Classical trade theories explain trade in similar goods under constant returns to scale and perfect competition. Factors of production are assumed mobile across sectors within one country, but immobile across countries. The basic versions of these models assume that two different final goods are produced (Yi, 2010). 
The assumption motivating trade in the Ricardian model is that countries have different relative labour productivities. It implies that under autarky, i.e. when countries do not trade at all with one another, the relative price of one good expressed in terms of the other good differs between the countries. In a hypothetical world without trade costs, this difference in relative prices opens up opportunities for welfare-enhancing international trade at a world price lying between the two autarky prices, which is determined by countries' consumption preferences and relative sizes (Markusen et al., 1995). At least one country specialises entirely in the production of the good in which it has a comparative advantage. Inefficient trade procedures result in trade costs that drive a wedge between the relative prices faced by the two countries. They now face international prices closer to their respective autarky price. They may continue to remain specialised, but there will be less consumption and trade and hence lower economic welfare. If trade costs become high enough, the international price faced by one country can become less favourable than its autarky price and trade ceases altogether, returning both countries to their autarky equilibria. Relative country sizes play a role in how likely this may happen. If one country is much larger, then the frictionless international price is already close to its autarky price, and trade ceases for smaller transaction costs (World Trade Report, 2015).

Freight transport is a vital component for the generation of welfare. It facilitates the movement of goods along a supply chain, and therefore it is indispensable for the supply of goods and directly influences the efficiency of the economy (Sönke, 2011). As a result, transport demand is closely linked to economic development. Between 1995 and 2008 the average annual growth of intraEuropean Union (EU-27) freight transport was 2\%. Hence, freight transport grew as fast as the economy, and during the economic downturn (2008-2009) when the GDP in EU-27 decreased by $4.2 \%$, freight transport dropped by $11.2 \%$ (European Commission, 2011). The amount and character of freight transport demand are determined by logistics decisions, which aim to move product efficiently along a supply chain. Changing logistics structures, e.g. decisions to centralise warehousing, and more just-in-time replenishment have led to increasing demand for the delivery of smaller units in higher frequency and the increasing importance of time, reliability and speed (McKinnon, 2003). The increasing demand for small volume goods flows at more frequent intervals has limited the scope of rail to maintain market shares (Woodburn, 2003) and many industries have increased their reliance on road transport. As a consequence, the growing demand for freight is mainly met by road while the market share of rail fell from $21 \%$ of total EU-27 inland freight transport in 1995 to $17 \%$ in 2008 (European Commission, 2011).

This development in the freight transport sector is a growing concern for sustainability since road freight is responsible for several negative impacts. These include impacts on the environment (e.g., atmospheric emissions, use of nonrenewable fuels, waste and loss of ecosystems), on society (e.g. public health, accidents, noise and reduction of quality of life) and on the economy (e.g. waste of resources and congestion resulting in decreasing journey reliability and city accessibility) (Quak, 2007). Freight transport, therefore, finds itself in constant tension between efficient logistics and sustainable development. On the one hand, narrow delivery time windows and smaller consignments make it more difficult to achieve economies of scale in transport operations, while on the other hand there is increasing pressure to reduce the environmental impact significantly. 
This challenge is most significant in urban areas. Urban freight transport serves industry and trade, which are essential wealth-generating activities (Anderson et al., 2005). For people, urban freight ensures the supply of goods in stores, and for firms, it forms a vital link with suppliers and customers (Crainic et al., 2004). Urban freight transport is, therefore, an essential component for the economic vitality of cities. However, the urban environment characterised by scarcity of access, e.g., congested roads, space constraints and limitations of infrastructure restricts the efficiency and quality of freight operations (Hesse and Rodrigue, 2004). Urban freight is also a threat to sustainable urban development and is increasingly perceived as a disturbing activity for passenger transport and citizens. Urban areas constitute the living environment of the majority of the population in Europe and the citizens' demands on the high quality of life increase (European Commission, 2007). Though freight transport operations in cities represent only $20 \%$ to $30 \%$ of road traffic, they account for up to $50 \%$ of the emission of air pollutants (depending on the pollutant considered) by transport activities in a city (Dablanc, 2007).

Wandel et al. (1992) present a hierarchical model for the analysis of logistics, transport and landuse that consists of the three layers freight flow, transport flow and infrastructure. It determines the demand for freight transport in terms of shipment size, frequency, lead-time, delivery precision and flexibility. The second layer is the transport network, which translates the freight transport demand into traffic. It provides transport services, resulting in actual load unit flows that generate demand for vehicle flows. The traffic is realised in an infrastructure layer that consists of, e.g., roads and rail tracks on which vehicle movements take place. The layers are connected by markets where supply and demand of the different layers are matched.

The hierarchical model of Wandel et al. (1992) represents the common perception that the demand for freight transport is derived from the economic activities that it serves and that the organisation of supply chains and transport networks determine the amount of traffic. Drewes-Nielsen et al. (2003) state that in this perspective, transport is perceived merely as a residual effect of logistics, which makes it challenging to isolate transport as an independent activity. On the other hand, transportation and logistics can also be seen as complementary systems, and there seems to be a growing acceptance to analyse transport as an activity embedded in its systemic logic in transport chains (Woxenius and Sjöstedt, 2003). In this perspective, logistics depends on the mobility of goods, which is enabled by transport networks bridging the distances between the economic activities. It is the location of the logistics activities about transport infrastructure that determines the nature, the origin, the destination, the distance and even the possibility of movements to be realised (Rodrigue et al., 2009).

Hence, improvements in freight transport capabilities can induce changes in logistics operations and hence foster transport demand (Hesse and Rodrigue, 2004). Transport networks and services are, therefore, inherently geographical as they link places together by enabling movements across space (Shen et al., 2009). The availability of transportation co-determines location decisions of economic facilities, which leads to changes in the land-use system (Geurs and van Wee, 2004). Economic activity, which is the foundation for regional welfare, requires high levels of accessibility to input materials and markets. Therefore, transport infrastructure opens up markets (Lakshmanan, 2011). However, access to transport services is unequal and restricted by location 
Vol.8 No.3, pp.1-16, August 2020

Published by ECRTD $\boldsymbol{U K}$

ISSN 2054-0930 (Print), ISSN 2054-0949 (Online)

due to unequal investment in transport nodes and links (Knowles, 2006). The regions with high levels of accessibility tend to be more competitive than peripheral and remote regions (Gutiérrez et al., 2009).

\section{METHODOLOGY}

Understanding such factors affecting freight movement either for production or for the attraction of a commodity is very important to produce a good model. A correlation model was first applied to establish whether a relationship between the freight volumes of the various nations and their respective gross domestic product (GDP). We then used regression analysis to generate models that can be used to estimate the generated freight volume nation-wide at different scenarios using the linear and non-linear ordinary least square method. The produced models were validated and tested for goodness of fit. The resulting models will estimate freight for any given nation knowing the values of the independent variables found to have a significant effect on the generation of freight volume such as GDP, population and exchange rate (used as a proxy for the cost of transport).

Since there is little available data at the sub-regional level, the model will estimate generationdistribution directly based on three parameters: GDP, Population and Exchange Rate (a proxy for the cost of shipment). Besides, the parameter was calculated to stimulate the growth of shipping operations between ECOWAS members.

The disaggregated econometric equation used in the model is as follows:

$\log V=\beta 1 \mathrm{~K}_{1} \log G D P \quad, \log V=\beta 1 \mathrm{~K}_{2} \log P O P \quad$ and $\log V=\beta 1 \mathrm{~K}_{3} \log C S T \quad \ldots$ Log-Linear models

$V=\mathrm{K}_{1}+\alpha_{1} G D P, V=\mathrm{K}_{2}+\alpha_{2} P O P$ and $V=\mathrm{K}_{3}+\alpha_{3} C S T$............ Linear models

Where

$\mathrm{V}=$ Freight Volume in metric tonnes transported in a given state

$\mathrm{K}=$ parameter of the state

$\mathrm{GDP}=\mathrm{GDP}$ for the origin zone

$\mathrm{POP}=$ Population at origin zone

$\mathrm{CST}=$ cost of shipping in the country (the exchange rate is used as a proxy)

$\alpha, \beta,=$ regression fitting parameters

\section{RESULTS}

This section describes the model specification and estimation results for the structural equation model. The models employed a host of exogenous (explanatory) and endogenous (dependent) variables to model freight volumes. Exogenous variables may be divided into three groups: population demographic characteristics of the origin and destination, Gross Domestic Product characteristics of the state and cost of freight movement in the country with Exchange rate as a proxy. All variables were derived from the ECOWAS database. Exogenous variables included in the models were selected based on earlier research literature. Endogenous variables are freight 
volumes at the various ECOWAS countries by mode. The freight volume on each mode is a different endogenous variable. The distributions of the endogenous variables are highly skewed and non-normal with no zero observations. 100 per cent of the observations are non-zero observations in the data set. Even within the context of the ordinary least square estimation method, such a heavily non-zero-inflated distribution leads to computational intractability. To help with computational tractability, log transformations of the variables are used in the estimation process. For all observations and variables, unity was not added to the raw variable value having to take the logarithm of non-zero, which is undefined. In this study, models were estimated for all the scenarios.

However, only four types of models are presented in this study to illustrate the model specification and estimation results. First, models are presented for total freight volumes by all commodity groups combined. Second, models are presented for maritime trade volumes. Thirdly, road transport trade models were computed similar to these models. Fourthly, models were formulated for the landlocked countries of Burkina Faso, Mali and Niger. As such, these models may be considered illustrative of the types of models that can be developed and applied using the database and methods described in this study. Structural equation models were estimated for all aggregate data across the ECOWAS countries. 
ISSN 2054-0930 (Print), ISSN 2054-0949 (Online)

Table 1: Aggregate ECOWAS Models showing freight movement in various scenarios

\begin{tabular}{|c|c|c|c|c|c|}
\hline \\
\hline Scenario & Model & $\mathrm{R}^{2}$ & F-stat & p-value & DW \\
\hline \multicolumn{6}{|c|}{ Aggregate Log-Linear Models } \\
\hline \multirow[t]{3}{*}{ Maritime Trade } & In $($ Maritime Trade Volume $)=-5271+\operatorname{In}(\text { GDP })^{0.686}$ & 0.532 & 14.801 & 0.002 & 2.787 \\
\hline & In $($ Maritime Trade Volume $)=-0.764+\operatorname{In}(\mathrm{POP})^{0.688}$ & 0.374 & 7.778 & 0.015 & 2.582 \\
\hline & $\operatorname{In}($ Maritime Trade Volume $)=2.374+\operatorname{In}(\text { EXR })^{-0.323}$ & 0.186 & 2.970 & 0.109 & 2.31 \\
\hline \multirow[t]{3}{*}{ Road Transport Trade } & $\operatorname{In}($ Road Trade Volume $)=-2.572+\operatorname{In}(\text { GDP })^{0.942}$ & 0.775 & 44.695 & 0.000 & 2.073 \\
\hline & $\operatorname{In}($ Road Trade Volume $)=3.442+\operatorname{In}(\mathrm{POP})^{1.032}$ & 0.651 & 24.293 & 0.000 & 1.764 \\
\hline & $\operatorname{In}($ Road Trade Volume $)=5.196+\operatorname{In}(E X R)^{0.049}$ & 0.003 & 0.044 & 0.838 & 2.183 \\
\hline \multirow[t]{3}{*}{ Total Trade } & In $($ Total Trade Volume $)=-2.507+\operatorname{In}(\mathrm{GDP})^{0.936}$ & 0.781 & 46.464 & 0.000 & 2.066 \\
\hline & In $($ Total Trade Volume $)=3.470+\operatorname{In}(\mathrm{POP})^{1.027}$ & 0.658 & 24.976 & 0.000 & 1.757 \\
\hline & $\operatorname{In}($ Total Trade Volume $)=5.244+\operatorname{In}(\text { EXR })^{0.044}$ & 0.003 & 0.035 & 0.855 & 2.183 \\
\hline \multirow[t]{3}{*}{ Land Locked Countries } & $\operatorname{In}($ Trade Volume $)=-4.706+\operatorname{In}(\mathrm{GDP})^{0.974}$ & 0.948 & 127.501 & 0.000 & 1.771 \\
\hline & $\operatorname{In}($ Trade Volume $)=-4.180+\operatorname{In}(\mathrm{POP})^{0.959}$ & 0.920 & 80.753 & 0.000 & 1.650 \\
\hline & $\operatorname{In}($ Trade Volume $)=2.026+\operatorname{In}(\mathrm{EXR})^{-0.406}$ & 0.175 & 1.484 & 0.263 & 0.462 \\
\hline \multicolumn{6}{|c|}{ Aggregate Linear models } \\
\hline \multirow[t]{3}{*}{ Maritime Trade } & Maritime Trade Volume $=-0.875+0.675 *$ GDP & 0.456 & 10.901 & 0.006 & 1.993 \\
\hline & Maritime Trade Volume $=0.420+0.514 * \mathrm{POP}$ & 0.264 & 3.582 & 0.088 & 2.805 \\
\hline & Maritime Trade Volume $=0.420-0.225^{*} \mathrm{EXR}$ & 0.051 & 0.533 & 0.482 & 2.330 \\
\hline \multirow{3}{*}{ Road Transport } & Road Trade Volume $=659.771+0.737 *$ GDP & 0.543 & 15.416 & 0.002 & 2.625 \\
\hline & Road Trade Volume $=553.956+0.732 * \mathrm{POP}$ & 0.536 & 15.037 & 0.002 & 2.537 \\
\hline & Road Trade Volume $=1328.763-0.228 * \mathrm{EXR}$ & 0.052 & 0.712 & 0.414 & 2.551 \\
\hline \multirow[t]{3}{*}{ Total Trade } & Total Trade Volume $=660.639+0.738 * \mathrm{GDP}$ & 0.545 & 15.578 & 0.002 & 2.625 \\
\hline & Total Trade Volume $=554.317+0.734 * \mathrm{POP}$ & 0.539 & 15.190 & 0.002 & 2.537 \\
\hline & Total Trade Volume $=1332.712-0.228^{*} \mathrm{EXR}$ & 0.052 & 0.713 & 0.414 & 2.548 \\
\hline \multirow{3}{*}{ Land Locked Countries } & Trade Volume $=-207.876+0.969 *$ GDP & 0.939 & 107.416 & 0.000 & 1.717 \\
\hline & Trade Volume $=-2345.391+0.965 * \mathrm{POP}$ & 0.931 & 94.349 & 0.000 & 1.783 \\
\hline & Trade Volume $=2624.811-0.310 * \mathrm{EXR}$ & 0.096 & 0.745 & 0.417 & 0.363 \\
\hline
\end{tabular}

Source: Compiled from SPSS 19.0 Output 
ISSN 2054-0930 (Print), ISSN 2054-0949 (Online)

Table 1 presents the structural equation model estimation results for all commodities combined. The models provided excellent goodness-of-fit measures with the F-statistic indicating that the model cannot be rejected with a high degree of confidence ( 95 per cent or higher) and with the goodness-of-fit index (GFI) equal to unity except for those with an exogenous variable of the exchange rates. Thus the models are capable of capturing the key relationships influencing freight volumes, even within the context of an extensive database where endogenous variables are highly skewed, zero-inflated, and non-normal. The indications provided by the four models are entirely consistent with expectations and are plausible. Table 1 shows the direct effects, indirect effects, and total effects that constitute relationships among variables. A direct effect is one where a variable directly affects another variable as depicted by a positive coefficient of the variables in the linear models. On the other hand, an indirect effect is one where a variable influences another variable through a mediating variable. For example, one can see that the exchange rate does not directly affect the total freight movement by all the examined scenarios.

However, the GDP and population of the countries affect total trade, maritime trade, road transport trade and Land-locked countries trade volumes. In some cases, a variable may have both a direct and indirect effect on another variable. Then the total effect is the sum of the direct and indirect effects. Table 12 shows that GDP and population have positive impacts on all trade volumes in the four scenarios. These coefficients represent how the total trade volumes among ECOWAS states respond to different scenarios.

Also, as expected, the total trade volume harms the exchange rates through their models are not statistically significant. It was initially expected that population variables would have a positive impact on the quantity of freight volume. However, estimation results show that population variables are associated with negative coefficients. The presence of a residential population does not necessarily contribute positively to freight volumes among nations. Within an urban area context, when one is concerned with the movement of goods and services within an urban area, then one may conjecture that both business establishments and residential population contribute positively to freight generation. However, within the context of a statewide freight volume analysis where the freight volumes are mostly industrial raw goods, the residential population is not likely to attract freight trips. Indeed, many industrial sites are located in places across most ECOWAS countries with minimal residential population and attract large amounts of freight volumes.

\section{Forecast of Freight Transport Demand of ECOWAS Nations}

Freight transport demand within the ECOWAS showed an upward trend throughout the year 2015 for Benin, Cape Verde, Ghana, Guinea, Guinea Bissau, Liberia and Nigeria. There was a downward trend for Burkina Faso, Cote d'Ivoire, Mali, Niger, Senegal, Sierra Leone and Togo. Between 2013 and 2015, freight volumes fell back to levels previously seen in 2004. The estimate for 2016, based on GDP as a proxy, suggests that freight transport demand may have fallen again in 2016 due to the economic recession experienced in most of the countries. 
European Journal of Logistics, Purchasing and Supply Chain Management

Vol.8 No.3, pp.1-16, August 2020

Published by ECRTD $\boldsymbol{U K}$

ISSN 2054-0930 (Print), ISSN 2054-0949 (Online)

Table 2: Forecast of Freight Transport Demand of ECOWAS Nations

\begin{tabular}{|l|l|l|l|l|l|}
\hline $\begin{array}{l}\text { ECOWAS } \\
\text { Nation }\end{array}$ & $\begin{array}{l}\text { GDP 2015 } \\
\text { (in a } \\
\text { million US } \\
\text { Dollars) }\end{array}$ & $\begin{array}{l}\text { Estimated } \\
\text { Maritime Freight } \\
\text { Demand for 2015 } \\
\text { (in a million } \\
\text { tonnes) }\end{array}$ & $\begin{array}{l}\text { Total Estimated } \\
\text { Freight Demand } \\
\text { for 2015 } \\
\text { (in a million } \\
\text { tonnes) }\end{array}$ & $\begin{array}{l}\text { Total Actual } \\
\text { Freight Transport } \\
\text { Demand for 2013 } \\
\text { (in a million } \\
\text { tonnes) }\end{array}$ & $\begin{array}{l}\text { Total Actual } \\
\text { Maritime Freight } \\
\text { Demand for 2013 } \\
\text { (in a million } \\
\text { tonnes) }\end{array}$ \\
\hline Benin & 8500 & 2.55 & 775.00 & 546.40 & 3.02 \\
\hline Burkina Faso & 12300 & 0 & 1096.14 & 1066.60 & 0 \\
\hline Cape Verde & 3400 & 1.36 & 328.11 & 13.70 & 0.81 \\
\hline Cote d'Ivoire & 31200 & 6.22 & 2625.31 & 7372.60 & 1.21 \\
\hline The Gambia & 920 & 0.55 & 96.31 & 196.00 & 0.76 \\
\hline Ghana & 36000 & 6.86 & 3002.62 & 1769.20 & 7.19 \\
\hline Guinea & 6700 & 2.17 & 619.94 & 54.70 & 1.23 \\
\hline $\begin{array}{l}\text { Guinea } \\
\text { Bissau }\end{array}$ & 1100 & 0.63 & 113.88 & 14.50 & 0.18 \\
\hline Liberia & 2000 & 0.94 & 199.48 & 31.20 & 0.46 \\
\hline Mali & 13100 & 0 & 1159.47 & 1572.80 & 0 \\
\hline Niger & 7200 & 0 & 660.97 & 764.80 & 0 \\
\hline Nigeria & 490000 & 41.14 & 34814.24 & 10451.00 & 2.21 \\
\hline Senegal & 13700 & 3.54 & 1212.81 & 1813.10 & 7.49 \\
\hline Sierra Leone & 4200 & 1.57 & 400.03 & 654.90 & 0.03 \\
\hline Togo & 4200 & 1.57 & 400.03 & 900.30 & 1.83 \\
\hline
\end{tabular}

Source: Computed by the Author (2016)

Maritime freight transport increased in 2015 in most of the ECOWAS nations except in Benin, The Gambia, Ghana and Senegal. Nigeria experience experienced phenomenal growth in maritime freight from 2.21 million tonnes in 2013 to 41.14 million tonnes in 2015 . The maritime modal share has remained relatively stable, meaning that growth in demand for maritime transport has been broadly in line with overall freight transport growth rates. Trade facilitation among the ECOWAS nations should be strengthened. Trade facilitation comprises a wide range of measures aimed at the simplification, harmonisation and standardisation of procedures affecting bordercrossing goods, including customs, regulatory issues, and insurance and banking aspects, and other measures that impact on the trans-border movement of goods. 


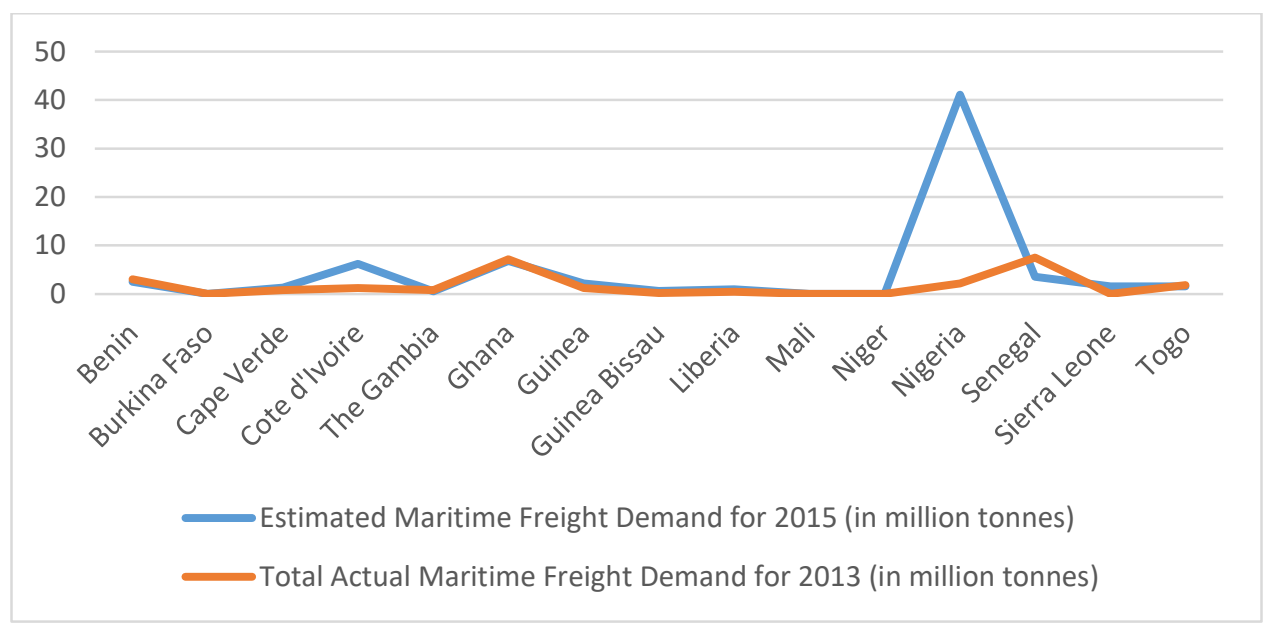

Fig. 1: Forecast of Maritime Freight Transport Demand of ECOWAS Nations

For landlocked countries, the main objective of trade facilitation is to increase the fluidity of goods in transit. Both landlocked and transit countries in ECOWAS should put particular emphasis on the simplification, harmonisation and standardisation of administrative and legal procedures related to customs, transit and port formalities at the regional level. The use of cargo information management systems can also facilitate and accelerate the physical movement of transit cargo. Modern and efficient transport infrastructure can contribute significantly to the economic development of landlocked countries by facilitating their beneficial participation in the process of globalisation, as well as by improving their international competitiveness and enhancing their potential role as hosts for foreign direct investment.

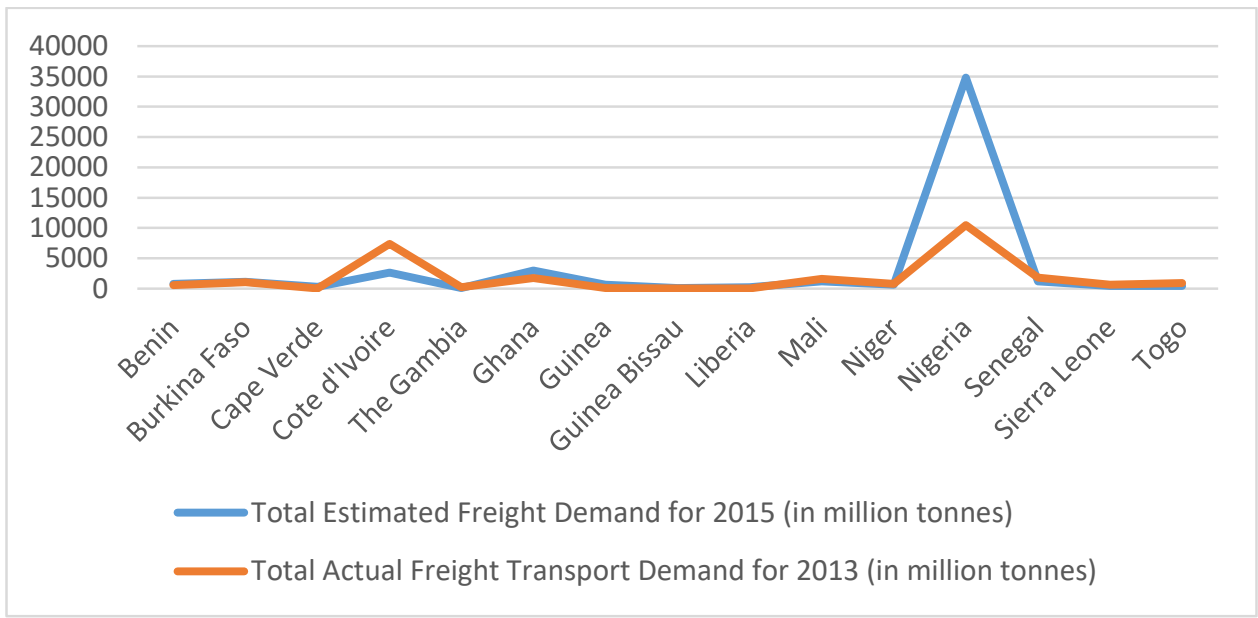

Fig. 2: Forecast of Total Freight Transport Demand of ECOWAS Nations 


\section{Short-Sea Shipping Model for ECOWAS Sub-Region}

Determinants of short sea shipping decisions on the freight volumes across the ECOWAS nations with maritime potentials are investigated by regressing the maritime freight demand (defined as the available maritime tonnes-kilometers) on the hypothesized explanatory variables: GDP, population, and number of port corridors available for each nation.

The weighted least square regression model is specified as follows:

Where,

$$
M T k m=\beta_{0}+\beta_{1} G D P+\beta_{2} P O P+\beta_{3} P A C+\varepsilon_{i}
$$

GDP $=$ Gross Domestic Product,

POP = Population, and

PAC $=$ Number of Seaport corridors available for each nation.

Table 3 shows the final structural equation model (SEM) specification results. The interpretation of the results in the table 3 is straightforward and consistent with economic theory. The first row in table 3 shows that the latent variable GDP acts as an exogenous variable on the latent variable maritime tonne-Kilometres with a coefficient estimate of 3.760. The second shows that population contributes negatively to maritime freight demand, implying that the growth in the population of the ECOWAS nation does not translate to economic gains possibly because greater population are redundant. Third row shows that maritime trade will respond positively to increase in the number of seaport corridors available in the ECOWAS nations. The fourth row presents the estimated intercepts of the observed endogenous variables.

\section{Table 3: Weighted Least Square Estimation} Results for Short-Sea Shipping Model

\begin{tabular}{ll}
\hline Variable & Model \\
\hline \multirow{2}{*}{ Gross Domestic Product } & $3.760^{* * *}$ \\
& {$[0.031]$} \\
Population (in millions) & $-2.851^{* *}$ \\
& {$[0.012]$} \\
No. of seaport corridors & $0.131^{*}$ \\
& {$[0.043]$} \\
Constant & 159.717 \\
& {$[0.641]$} \\
\hline$R^{2}$ & \\
Adjusted $R^{2}$ & 0.987 \\
$\mathrm{~F}$ & 0.982 \\
\hline
\end{tabular}


ISSN 2054-0930 (Print), ISSN 2054-0949 (Online)

Table 4 shows various goodness-of-fit statistics used during model selection. The chi-square value for the final model is 1.500 with 11 degrees of freedom ( $p$ value of 0.000 ), which indicates the model fit cannot be rejected at $p=0.05$. Because the chi-square goodness-of-fit test is used to test for differences between the implied model variance covariance matrix and the observed one, a model that will not reject the null hypothesis is a desired outcome. The RMSEA for the final model was 0.003 , which clearly indicates a close-fitting model.

Table 4: Overall Goodness-of-Fit Measures for Short-Sea Shipping Model

\begin{tabular}{lll}
\hline Description & Final Model & p-value \\
\hline Chi-square & 1.500 & 0.000 \\
RMSEA & 0.003 & \\
Normal fit index & 0.993 & \\
Tucker-Lewis index & 0.993 & \\
& & \\
\hline
\end{tabular}

Key: RMSEA = root mean square error of approximation

As a major strength favouring short-sea shipping, the geographical environment of ECOWAS subregion can be considered: the facile accessibility of ports combined with the considerable total coastline of about $5,286 \mathrm{~km}$, provides a good competitive environment for short-sea shipping. Additionally, most of the industrial and productive centres of ECOWAS member countries are located around the coastline. Another big strength of short-sea shipping is the possibility to carry higher volumes than other modes and thus resulting in a better use of economies of scale. The economies of scale allow short-sea shipping to offer services at lower freight rates and therefore exploit an underused available capacity without incurring high capacity-related investment costs.

Based on the fact that short-sea shipping is a capital-intensive industry, the market has higher entry barriers compared to the road mode. This gives operators already in the market the advantage to develop transport systems/route networks where the most capital intensive mode is already present.

Furthermore, the sea has an unlimited traffic capacity. While there is the challenge of congestion on landside modes, the capacity of the sea is virtually unlimited and the demand of infrastructural maintenance or expansion is by far lower, but however expensive. Short-sea shipping does not require sea lanes but only superstructure along the coast that may contribute to safety of navigation. As a result investment in short sea shipping infrastructure can also be seen as an investment in the attractiveness of short-sea shipping, for example a vessel traffic management information system which helps to guard the effect of the broken transport chain. Paixao and Marlow (2002) contend that consequently the cost of port maintenance and port investments is low compared to all land transport modes, especially by considering the external costs such as congestion and pollution. The only external cost necessary for a short-sea shipping business and might be carried by "not directly involved participants" is an adequate port infrastructure which needs to handle entry and exit of goods by avoiding congestion. This however has to be organized on a mutual basis with the involvement among different players to prevent the existence of bottlenecks in transport chains. 
Paixao and Marlow (2002) reiterates that this situation implies that short-sea shipping does not need innovation in the form of new investments in infrastructure, but the performance can be easily increased by the cooperation of short-sea shipping and business related players. The implementation of a new philosophy would increase the flexibility, creativity, integrity, leadership and openness to learning, which will help to handle market uncertainties and new logistical challenges like Just-in-Time (JIT). Related to the capital intensity, which gives the players of the short-sea shipping business a competitive edge, there is also the skill and knowledge level of the players acting as a high entrance barrier (Paixao and Marlow 2002).

\section{Short Sea Shipping Scenario: Evidence in Nigeria}

Nigeria is commonly referred to as the largest economy in the ECOWAS sub-region based on her over 160 million population; robust economic resources; vast hinterland; hug GDP and a vibrate political economy. With $853 \mathrm{~km}$ of coastline and network of inland waterways, Nigeria's share of the total shipping activities in volume and value in the ECOWAS sub-region is well over $70 \%$. Nigeria, therefore, provides a typical scenario for short sea shipping potential in the ECOWAS sub-region within the context of her inland waterways transportation potential. Analysis of the Nigeria scenario would reasonably reflect the current general situation and future trend of short sea shipping in the ECOWAS sub-region.

As mentioned earlier, Nigeria has a vast coastline which she bordered on the western flank with the Republic of Benin from where it extends to the rest of the other ECOWAS littoral countries. The coastline in her eastern flank is bordered with Cameroon and extends to the central African sub-region. Nigeria, therefore, is strategically located at the epic-centre of coastal shipping activities between two famous African sub-region. The prime coastal location is further complemented by two major rivers - the River Niger and River Benue, which formed a vital confluence at Lokoja to flow southward. It drains into the Atlantic Ocean through an excellent network of deltas and creeks in the Niger Delta area of Southern Nigeria. The Rivers Niger and Benue, which confluence at Lokoja, divided Nigeria into three almost equal parts. They both have essential tributary rivers that combine to give Nigeria a network of inland waterways that link some critical economic and political centres.

While River Niger connects Nigeria with the countries of Benin, Niger, Mali and Guinea, where it has its watershed, the River Benue connects Nigeria with Cameroon on her Eastern border. The two rivers provide inland waterways transportation possibility between Nigeria and these ECOWAS member countries as well as the countries of Central African Republics of Cameroon and her neighbours.

\section{CONCLUSION}

For brevity, four structural models are formulated for the study to illustrate the model specification and estimation results. First, models for total freight volumes by all commodity groups combined. Second, models for maritime freight volumes. Thirdly, models for road freight volume and fourthly, models for the freight volumes of the landlocked countries of Burkina Faso, Mali and Niger. Finally, a model equation for forecasting short sea shipping freight growth is formulated. 
These models may be considered illustrative of the types of models that can be developed and applied using the database and methods described in this study. Structural equations models were estimated for all aggregate data across the ECOWAS countries. Thus the models are capable of capturing the key relationships influencing freight volumes, even within the context of an extensive database where endogenous variables are highly skewed, zero-inflated, and non-normal. The indications provided by the four models are entirely consistent with expectations and are plausible.

As a critical factor in favour of short-sea shipping, the geographical environment of the ECOWAS sub-region can be considered as a perfect setting in view of: the easy accessibility of ports combined with the considerable total ECOWAS coastline of about 5,286km offers an excellent competitive environment for short-sea shipping. Additionally, most of the industrial and production centres in the ECOWAS sub-region are located around the coastline. Another major fundamental strength of short-sea shipping is the potential to carry higher volumes than other modes and thus resulting in better use of economies of scale. The economies of scale allow shortsea shipping to offer services at lower freight rates and therefore exploit underused available capacity without incurring high capacity-related investment costs.

\section{References}

Anderson, J. E. and Van Wincoop, E. (2004). Trade Costs, Journal of Economic Literature 42(3): 691-751.

Anderson, S., Allen, J. and Browne, M. (2005). Urban logistics-how can it meet policy makers' sustainability objectives? Journal of Transport Geography, 13 (1): 71-81.

Crainic, T. G., Ricciardi, N. and Storchi, G. (2004). Advanced freight transportation systems for congested urban areas, Transportation Research Part C: Emerging Technologies, 12 (2): 119-137.

Dablanc, L. (2007). Goods transport in large European cities: Difficult to organise, challenging to modernise", Transportation Research Part A: Policy and Practice, 41 (3): 280-285.

Drewes Nielsen, L., Homann Jespersen, P., Petersen, T., et al. (2003). Freight transport growth--a theoretical and methodological framework", European Journal of Operational Research, 144 (2): 295-305.

European Commission (2007). Green Paper: Towards a new culture for urban mobility, Luxembourg.

European Commission (2011). EU transport in figures: Statistical pocketbook 2011, Luxembourg.

Geurs, K. and Van Wee, B. (2004). Land-use/transport Interaction Models as Tools for Sustainability Impact Assessment of Transport Investments: Review and Research Perspectives, European Journal of Transport and Infrastructure Research, 4 (3): 333-355.

Gutiérrez, J., Kitchin, R. and Thrift, N. (2009). Transport and accessibility, (ed.), International Encyclopedia of Human Geography, Elsevier, Oxford, 410-417.

Hesse, M. and Rodrigue, J. P. (2004). The transport geography of logistics and freight distribution", Journal of Transport Geography, 12 (3): 171-184.

Knowles, R. D. (2006). Transport shaping space: differential collapse in time-space, Journal of Transport Geography, 14 (6):407-425. 
Krugman, P. (1979). Increasing Returns, Monopolistic Competition and International Trade, Journal of International Economics 9(4): 469-479.

Krugman, P. (1980). Scale Economies, Product Differentiation and Pattern of Trade", American Economic Review 70(5): 950-959.

Lakshmanan, T. R. (2011). The broader economic consequences of transport infrastructure investments, Journal of Transport Geography, 19 (1): 1-12.

Markusen, J. R., Melvin, J. R., Kaempfer, W. H. and Maskus, K. E. (1995). International Trade, Theory and Evidence, New York: McGraw-Hill.

Melitz, M. J. (2003). The Impact of Trade on Intra-Industry Reallocations and Aggregate Industry Productivity, Econometrica 71(6): 1695-1725.

Paixao, A.C. and Marlow, P.B., (2002). The Strengths and Weaknesses of Short Sea Shipping, Marine Policy, 26, 167-178

Quak, H. (2007). Sustainability of urban freight transport - Retail Distribution and Local Regulations in Cities. Erasmus Research Institute of Management (ERIM). Rotterdam, Erasmus University. PhD.

Rodrigue, J. P., Comtois, C. and Slack, B. (2009). The geography of transport systems, Routledge, Abingdon, Oxon, England; New York.

Shen, S., T. Fowkes, T. Whiteing \& D. Johnson (2009). Econometric Modelling and Forecasting of Freight Transport Demand in Great Britain. ETC Conference Proceedings.

Sönke Behrends (2011). Urban freight transport sustainability: The interaction of urban freight and intermodal transport. Thesis for the Degree of Doctor of Philosophy. Department of Technology Management and Economics, Chalmers University of Technology, SE-412 96 Gothenburg Sweden.

Wandel, S., Ruijgrok, C. and Nemoto, T. (1992). Relationships among shifts in logistics, transport, traffic and informatics, M. Huge and N. G. Storhagen (ed.), Logistiska Framsteg - Nordiska forskningsperspectiv på logistik och materialadministration, Studentlitteratur, Lund, 96136.

World Trade Report (2015). The theory and measurement of trade facilitation: Speeding up trade: benefits and challenges of implementing the WTO Trade Facilitation Agreement. Retrieved from

https://www.wto.org/english/res_e/booksp_e/wtr15-2c_e.pdf on 22 April 2016.

Woxenius, J. and Sjöstedt, L. (2003). Logistics trends and their impact on European combined transport-services, traffic and industrial organisation, (ed.), Logistik-management, 134-147

Yio, K. M. (2010). Can Multistage Production Explain the Home Bias in Trade? American Economic Review 100(1): 364-393. 